\title{
An Examination of the Inclusion of a Sample of Selected Women Authors in Books for College Libraries
}

Lynn Silipigni Connaway

This exploratory study identifies some of the characteristics of the three editions of Books for College Libraries (BCL) in relation to literature by women. A sample of fifty authors selected from The Norton Anthology of Literature by Women: The Tradition in English, a canon in the field of women's studies, is compared to the holdings of $\mathrm{BCL}$, a highly respected core bibliography for undergraduate libraries. Forty-two of the fifty authors in the sample are included in BCL. Three hundred eighteen unique titles appear in BCL for the sample of authors. Sixty-four percent of the publishers of the titles in this study that appear in BCL are published by trade publishing companies.

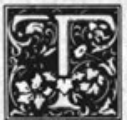

he American Library Association has published three editions of Books for College Libraries $(B C L)$. The first edition of Books for College Libraries (BCL1) was intended to update Charles B. Shaw's 1931 List of Books for College Libraries. It is a list of approximately 53,400 titles based on the initial selection made for the University of California's New Campuses program and selected with the assistance of college teachers, librarians, and other advisers. "The size and subject balance of the list are similar to the already successful working collections of the Lamont Library at Harvard University and the Undergraduate Library at the University of Michigan." ${ }^{11}$ As the preface to BCL1 states, "This list does not claim to be a list of the best books or a basic list for any college library ... [it] is a list of monographs designed to support a college teaching program that de- pends heavily upon the library, and to supply the necessary materials for term papers and suggested and independent outside reading." 2

The following two editions of $B C L$ state similar objectives. BCL2, which appeared in 1975, states in the "Introduction" that it is intended for use by the same audience of undergraduate libraries as $B C L 1$ and that the number of titles included has been reduced to 38,651 to reflect a minimal "core collection." ${ }^{\prime 3}$ The "Introduction" further states, "Books recommended were to constitute 'the bare minimum of titles needed to support an average college instructional program of good quality." duction" to the third edition of $B C L$ $(B C L 3)$, which appeared in 1988, again states that the list "presents a third recommended core collection for undergraduate libraries. . . ." ${ }^{5} \mathrm{BCL} 3$ includes 50,000 titles.

Lynn Silipigni Connaway is Assistant Professor at the University of Missouri-Columbia School of Library and Informational Science, Columbia, Missouri 65211. The author would like to thank John M. Budd, School of Library and Informational Science, University of Missouri-Columbia, and Wayne A. Wiegand, School of Library and Information Studies, University of Wisconsin-Madison, for their thoughtful comments and suggestions and for their encouragement to complete this study. 
The three editions of $B C L$ have been subject to similar criticisms. The major criticism is the inclusion of a substantial number of out-of-print publications. Lee Ash and Robert W. Wadsworth criticize the fact that at least 40 percent of those titles included in BCL1 were out of print at the time the edition was published. ${ }^{6} \mathrm{R}$. E. Moore and Lee Ash criticize the inclusion of out-of-print titles when available reprints of the titles are not listed in $B C L 2$. $^{7}$ John Budd selected a stratified sample of 381 titles listed in BCL3 and checked for in-print status. ${ }^{8}$ Of these 381 titles, 163 (about 43 percent) were out of print approximately one year after the publication of $B C L 3$. Although each edition of $B C L$ specifically states the titles were selected without regard to their availability from publishers and in-print availability was not considered a major factor, this does pose limitations on the lists as guides for selection.

The reviewers also question the qualifications of those responsible for selection in each specialized area of BCL2.9 $B C L 3$ attempted to correct this doubt of authority by involving more than four hundred faculty members and about fifty academic reference librarians on "the first-round team" and sixty-four academic librarians on the reviewing group for the second round. ${ }^{10}$ The librarians reviewed broader subject areas than the faculty reviewers. The first-round team members were given pages from $B C L 2$ and Choice review cards within their subject areas. They were asked to rank the titles on a scale of one through four and to recommend other titles they believed necessary for undergraduate study within their subject areas. The second-round group served as referees and rated the quality and appropriateness of the firstround contributors' selections. ${ }^{11}$

The producers of $B C L 2$ are also criticized for their unbalanced and uneven selections, as well as the omission of important works. ${ }^{12}$ Thomas Gaughan charges BCL2 with emphasizing secondary authors and slighting major authors. ${ }^{13}$ Wadsworth berates BCL2's "striking reduction in number of titles" for specific authors in comparison to BCL1. ${ }^{14}$
Regardless of the criticisms, the literature suggests that $B C L$ is used for evaluating and assessing collections as well as for building and maintaining them. ${ }^{15}$ With the increasing number of revisions and additions to the academic curriculum, the need for and use of a core collection guide may be essential in developing collections to support the undergraduate curriculum. It is fairly common for small and medium-sized academic libraries to evaluate the quality of their collections by using basic lists. Stanley Shabowich describes the process used to judge the quality of a library collection by checking the library's holdings against $B C L .{ }^{16}$ Since $B C L$ proposes to represent a core collection that is designed to support the curriculum of four-year institutions, to be used as a measure to evaluate academic library collections, and to be considered an important canon of the library field, it is also likely to be consulted when building collections to support new courses, programs, and departments. ${ }^{17}$

Because the last twenty years have seen the steady growth of women's studies courses, programs, and academic departments, $B C L$ is one of the guides likely to be consulted for building core collections in support of this field. ${ }^{18}$ Women's studies has gained scholarly recognition and legitimacy as an area of study within academia during this time period.

Although feminist scholarship was first integrated into the fields of history and literature, it has expanded into the fields of the social sciences and professions and is currently spreading to technology and the biological sciences. ${ }^{19}$ Colleges and universities have integrated and are continually integrating scholarship on women and nonwhite cultural groups into the liberal arts core curriculum..$^{20}$ The study and mainstreaming of gender within a discipline have grown in the 1980 s, especially within undergraduate programs. ${ }^{21}$ Since women's studies draws upon the knowledge of many disciplines, with women as the center of intellectual inquiry, it is considered interdisciplinary or transdisciplinary. ${ }^{22}$ By incorporating the study of 
women into the courses of other disciplines, feminist faculty hope to integrate women's values and women's concerns into the center of liberal education. ${ }^{23}$

\section{THE LITERARY CANON}

In any investigation of an academic core curriculum for literature, the issue of canon must be confronted. Many widely read and popular women authors remain excluded from or in the margins of the literary canon. The exclusion of women writers from the canon and their marginal place in literature have been widely challenged during the 1980 s. The challenge is attributed to the scholars, critics, and reviewers who defined and codified the American literary canon in relation to the masculine world of contemporary social and economic issues and is synonymous with power. ${ }^{24}$

In her discussion of the decanonization of Willa Cather, O'Brien attributes Cather's establishment as a major writer in the 1920 s to her first supporters, "journalists and men of letters who waged their campaign for a national literature with a 'distinctively American spirit' outside the academy." ${ }^{\prime 25} \mathrm{O}^{\prime} \mathrm{Brien}$ then attributes Cather's demotion from a major to minor writer in the 1930 s and 1940 s to her later critics, "teachers of literature within English departments as well as book reviewers and authors of literary histories. ${ }^{26}$ Robert Alter writes:

Literature, as has often been claimed over the past quarter century, is neither a stable nor a coherent entity. One way you can tell this is by the shifting nature of the literary canon. As cultural fashions change and new values come to the fore, writers once deemed peripheral or uncanonical are brought into the canon, others once thought central, being displaced to the margins. ... [This movement suggests] that there may be something arbitrary and indeed slanted about the canon. Literature, then, according to this line of reasoning is not a fixed entity, but a reflection in any society of the values of the ruling class, abetted by a learned or priestly elite. ${ }^{27}$
If Alter's line of logic is extended to Willa Cather, she was regarded as a major author by the values of society in the 1920 s and, in turn, was regarded as a minor author by the societal values of the 1930 s and $1940 \mathrm{~s}$. With the support of this literature, the literary canon is defined not as a fixed entity, but as a reflection in any society of the values supported or favored by a learned elite.

Since literary anthologists are believed heavily to influence the canon and literary anthologies are believed to identify the major and minor authors of the time, The Norton Anthology of Literature by Women: The Tradition in English (NALW) is considered an important canon of women authors. ${ }^{28}$ This is also revealed in library and popular journal reviews. The $N A L W$ is characterized as a landmark in feminism, as well as in the study of literature and a solid work that is sure to be a staple in undergraduate English classes. ${ }^{29-31}$

In the "Preface" to the NALW, Sandra M. Gilbert and Susan Gubar specifically state that the anthology was designed to serve as a core curriculum for women's literature courses and as the canon into which other women authors may be assimilated. ${ }^{32}$ In the "Preface" to the anthology the authors apologize for excluding countless women writers, many of whom originated from ethnic backgrounds, but attribute this exclusion to limited space and copyright restrictions. Like other Norton anthologies, the NALW is arranged in chronological order followed by introductions to the historical sections.

Like $B C L, N A L W$ has encountered its criticisms. Gilbert and Gubar have been criticized for selecting authors for the $N A L W$ to support a case against men or a seventies-style political sentimentality or to document and connect female literary experience rather than to present distinguished literary merit. ${ }^{33}$ Others condemn the authors of the NALW for promoting exactly that which it is supposed to critique - the exclusion of black, Chicano, and Native American Indian women and the adaptation to the standard Norton anthologies of authenticating writers by including them in the 
traditional male canon. ${ }^{34}$ Gilbert and Gubar explain the exclusion of authors in the "Preface." ${ }^{135}$ Shari Benstock justifies the style of the anthology by stating that $N A L W$ 's adaptation of the style of other male-dominated Norton anthologies was to suggest that woman's place is within man's history and to "suggest the ways in which woman is sewn into (and sewn up by) the patriarchal system." ${ }^{\prime 36}$

Despite the negative reviews and flaws of the NALW, it has been lauded as a landmark not only in feminist commentary but in the study of literature. ${ }^{37}$ The reviewer for Library Journal recommends most libraries purchase at least two copies of the NALW, one for reference and one for circulating. ${ }^{38}$

\section{THE STUDY AND ITS METHODOLOGY}

The number of women's studies courses offered in colleges and universities has grown from sixteen courses in 1969 to over twenty thousand courses in the $1980 \mathrm{~s}^{39}$ Therefore, the implications of the utility of $B C L$ in evaluating, assessing, building, and maintaining collections to support the women's studies curriculum of undergraduate programs will be examined in this study.

Specifically, this study looks at the inclusion of women authors in the field of literature in the three editions of $B C L$ with an eye on support for the women's studies curriculum of undergraduate programs in four-year academic institutions. This allows for a comparison of approximately twenty years in relation to the publishing dates of the three editions of $B C L$ and the emergence and growth of women's studies as a discipline. Since the $N A L W$ is considered an important canon of women authors in the field of literature, it is compared to the holdings of the three editions of $B C L$. Other anthologies, such as the Norton and Oxford anthologies and The Great Books of the Western World are not used because of their limited inclusion of women authors.

The apportionment of authors within each chronological division in the NALW is:

- Literature of the Middle Ages and the

Renaissance -5 ( 3.4 percent)
- Literature of the Seventeenth and Eighteenth Centuries - 15 (10.2 percent)

- Literature of the Nineteenth Century -23 (15.5 percent)

- Turn-of-the-Century Literature-13 (8.8 percent)

- Modernist Literature-31 (20.9 percent)

- Contemporary Literature-61 (41.2 percent)

Sampling is employed in order to ensure representativeness within chronological periods and as an exploratory tool to investigate inclusion in $B C L$. A systematic sample includes the first author listed in the anthology and then every third author listed throughout NALW for this study. The sample consists of fifty authors selected from the total of 148 authors included in the NALW. This sample is also proportional to the number of authors included in each chronological division. The apportionment of the sample of fifty authors within each chronological division is:

- Literature of the Middle Ages and the Renaissance-2

- Literature of the Seventeenth and Eighteenth Centuries-5

- Literature of the Nineteenth Century -8

- Turn-of-the-Century Literature-4

- Modernist Literature-10

- Contemporary Literature-21

The sample of fifty authors within each chronological division is included in appendix $\mathrm{A}$.

Each edition of $B C L$ is checked for the inclusion of each author included in the $N A L W$. For every author included in the $N A L W$, the inclusion or exclusion of the author in each edition of $B C L$ is documented. For each author in the sample included in $B C L$, the following information is documented: the title, publisher, and publication date of the work and the edition, volume number, entry number, page number, and subject heading of the citation in $B C L$.

By documenting this information, the study identifies (1) the women authors of literature included in The Norton Anthology of Literature by Women and in each of the three editions of Books for College Libraries; (2) the titles of the works 
written by the sample of fifty authors included in any of the three editions of Books for College Libraries; (3) the titles of the works written by the sample of fifty authors included in all three editions of Books for College Libraries; and (4) the characteristics and trends of the authors and titles included in Books for College Libraries.

\section{FINDINGS}

The NALW is included in BCL3 under the subject heading "American Literature. Special Classes of Authors." Fortytwo of the fifty authors in the sample are included in at least one of the editions of $B C L$. Of the 148 authors included in $N A L W$, twenty-nine are not included in any edition of $B C L$. The number of authors included in both $N A L W$ and $B C L$ is 119 or about 80 percent, while twentynine authors or just over 19 percent are not included in $B C L$. Table 1 presents the number and percentage of authors included in NALW and in BCL by chronological divisions.

Table 2 presents the number and percentage of authors included in NALW and in the three editions of $B C L$ by chronological divisions.

The mean percentage of authors represented in BCL1 is about 54 percent. Seventeen of the contemporary authors included in NALW had not published their works until after 1967 and most of those who had published prior to BCL1's 1967 publication date had not yet achieved critical acclaim.

The percentage of authors from the Middle Ages and the Renaissance repre- sented in BCL2 is a 20 percent decline from $B C L 1$; however, the representation of the modernist authors in BCL2 remains consistent with the representation in BCL1. The representation of authors in the seventeenth and eighteenth centuries, nineteenth century, turn-of-the-century, and contemporary divisions in $B C L 2$ indicates an increase in representation from BCL1. Four of the contemporary authors included in NALW had not published their works until after 1975 , the publication date for BCL2. The mean percentage of authors represented in $B C L 2$ is nearly 56 percent.

The percentage of authors represented in BCL3 in the Middle Ages and the Renaissance is equivalent to the percentage represented in $B C L 1$, which is greater than the percentage represented in BCL2. The percentage of authors represented in $B C L 3$ in the turn-of-the-century is equivalent to the percentage represented in $B C L 1$ and is less than the percentage represented in BCL2. The representation of authors in the seventeenth and eighteenth centuries, nineteenth century, modernist, and contemporary divisions in BCL 3 indicates an increase in representation from $B C L 1$ and $B C L 2$. The mean percentage of authors represented in $B C L 3$ is about 70 percent.

The eight authors from the fifty author sample, within the chronological divisions, who are not included in $B C L$ are:

\section{Literature of the Seventeenth and Eighteenth Centuries}

- Margaret Cavendish, Duchess of Newcastle (1623-74)

TABLE 1

\begin{tabular}{lccc}
\multicolumn{4}{c}{ NUMBER AND PERCENTAGES OF AUTHORS INCLUDED IN NALW AND BCL } \\
\hline $\begin{array}{l}\text { Chronological } \\
\text { Division }\end{array}$ & $\begin{array}{c}\text { Number of } \\
\text { Authors Included } \\
\text { in NALW }\end{array}$ & $\begin{array}{c}\text { Number of } \\
\text { NALW Authors } \\
\text { Included in } B C L\end{array}$ & $\begin{array}{c}\% \text { of } \\
\text { Authors } \\
\text { Included in } B C L\end{array}$ \\
\hline $\begin{array}{l}\text { Middle Ages and the } \\
\text { Renaissance }\end{array}$ & 5 & 4 & 80 \\
17th and 18th centuries & 15 & 9 & 60 \\
19th century & 23 & 20 & 87 \\
Turn-of-the-century & 13 & 12 & 92 \\
Modernist & 31 & 24 & 77 \\
Contemporary & 61 & 50 & 82 \\
\hline
\end{tabular}


TABLE 2

NUMBER OF AUTHORS INCLUDED IN NALW AND THE THREE EDITIONS OF BCL

\begin{tabular}{|c|c|c|c|c|c|c|c|}
\hline \multirow{2}{*}{$\begin{array}{l}\text { Chronological Division } \\
\text { of Authors Included } \\
\text { in NALW }\end{array}$} & \multirow{2}{*}{$\begin{array}{c}\text { Number of } \\
\text { Authors } \\
\text { Included in NALW }\end{array}$} & \multicolumn{2}{|c|}{$\begin{array}{l}\text { NALW Authors } \\
\text { Included in } \\
B C L 1 \text { (1967) } \\
\end{array}$} & \multicolumn{2}{|c|}{$\begin{array}{l}\text { NALW Authors } \\
\text { Included in } \\
B C L 2 \text { (1975) } \\
\end{array}$} & \multicolumn{2}{|c|}{$\begin{array}{l}\text { NALW Author: } \\
\text { Included in } \\
B C L 3 \text { (1988) }\end{array}$} \\
\hline & & No. & $\%$ & No. & $\%$ & No. & $\%$ \\
\hline Middle Ages and the & 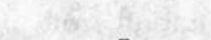 & & & & & & \\
\hline Renaissance & 5 & 2 & 40 & 1 & 20 & 2 & 40 \\
\hline 17 th and 18 th centuries & 15 & 4 & 27 & 6 & 40 & 9 & 60 \\
\hline 19th century & 23 & 13 & 56 & 15 & 65 & 20 & 87 \\
\hline Turn-of-the-century & 13 & 10 & 77 & 11 & 85 & 10 & 77 \\
\hline Modernist & 31 & 20 & 64 & 20 & 64 & 23 & 74 \\
\hline Contemporary & 61 & 24 & $58^{*}$ & 34 & $60^{\dagger}$ & 49 & 80 \\
\hline $\begin{array}{l}\text { Total number of } \\
\text { authors }\end{array}$ & 148 & 73 & $56^{*}$ & 87 & $60^{\dagger}$ & 113 & 76 \\
\hline
\end{tabular}

* NALW includes 61 authors in the Contemporary period, however only 44 of these authors published before 1967, the publication date for BCL1.

+ NALW includes 61 authors in the Contemporary period, however only 57 of these authors published before 1975 , the publication date for $B C L 2$.

- Mary Rowlandson (c.1636-c.1678)

- Anne Killigrew (1660-85)

\section{Turn-of-the-Century Literature}

- Charlotte Mew (1870-1928)

\section{Modernist Literature}

- Anna Wickham (1884-1947)

- Anzia Yezierska (c.1885-1970)

\section{Contemporary Literature}

- Kamala Das (1934-)

- Maxine Hong Kingston (1940-)

The demographics of both the fortytwo authors included in $B C L$ and the eight authors not included in $B C L$ are of interest to this study. Of the forty-two authors included in $B C L$, six of the women are women of color (Phyllis Wheatley (black slave), Linda Brent (black slave), Mourning Dove (Native American), Gwendolyn Brooks (African American), Toni Morrison (African American), and Leslie Marmon Silko (Native American, Mexican, and Caucasian descent); eight are writers concerned with women's issues (Margaret Fuller, Elizabeth Cady Stanton, Louisa May Alcott, Virginia Woolf, Djuna Barnes, Tillie Olsen, Marge Piercy, and Margaret Drabble); two are known to be lesbians or bisexual (Virginia Woolf and Djuna Barnes); three lived with a female companion in a union comparable to marriage (Sarah Orne Jewett, Willa Cather, and Gertrude Stein); three are Jewish (Gertrude Stein, Lillian Hellman, and Grace Paley); seven are poets (Mary Sidney Herbert, Countess of Pembroke; Dorothy Wordsworth and Elizabeth Drew Stoddard (both wrote some poetry); Emily Dickinson; Mary Elizabeth Coleridge; Edith Sitwell; and Judith Wright.) Twenty-five of the forty-two authors included in $B C L$ are American writers: Phyllis Wheatley, Margaret Fuller, Elizabeth Cady Stanton, Linda Brent, Elizabeth DrewStoddard, Emily Dickinson, Louisa May Alcott, Sarah Orne Jewett, Willa Cather, Gertrude Stein, Mourning Dove, Djuna Barnes, Lillian Hellman, Eudora Welty, Mary McCarthy, Tillie Olsen, Gwendolyn Brooks, Grace Paley, Flannery O'Connor, Ursula K. LeGuin, Toni Morrison, Marge Piercy, Joyce Carol Oates, Louise Gluck, and Leslie Marmon Silko. Four held unconventional political beliefs (this is addressed below): Tillie Olsen, Judith Wright, Lillian Hellman, and Marge Piercy. ${ }^{40}$

Six of the authors' works address unconventional perspectives on society or 
controversial social problems and subjects. These authors are Lady Mary Wortley Montagu, Elizabeth Drew Stoddard, Jean Rhys, Tillie Olsen, Judith Wright, and Marge Piercy. One of the authors, Ursula K. LeGuin, is a science fiction writer.

Of the eight authors not included in $B C L$, four are poets (Anne Killigrew, Charlotte Mew, Anna Wickham, and Kamala Das). Four are American (Mary Rowlandson, Anne Killigrew, Anzia Yezierska, and Maxine Hong Kingston); three are English (Margaret Cavendish, Charlotte Mew, and Anna Wickham); and one is East Indian (Kamala Das). One of the authors, Maxine Hong Kingston, is Chinese American and one, Anzia Yezierska, is Jewish. Yezierska was a Jewish immigrant who lived in New York and wrote of the assimilation process. ${ }^{11}$ Kamala Das writes in an "English fashioned to retain Indian cadences." ${ }^{\prime \prime 2}$ Maxine Hong Kingston is one of the only Chinese-American authors to be included in the canon of women's literature. ${ }^{43}$

Charlotte Mew was "passionately attached to another woman" and dressed as a transvestite. ${ }^{44}$ Margaret Cavendish was regarded as a freak by her contemporaries because of "the oddity of her writings and the peculiarity of her dress." ${ }^{15}$ Anna Wickham was said to be "a woman who lived by her own rules" and "a rebellious wife." ${ }^{\prime \prime 6}$ Mary Rowlandson wrote about her captivity with a New Hamp- shire Indian tribe and described the Indians as humans rather than beasts.

An examination of the demographics listed above, suggests that the majority of female authors included in $B C L$ are not women of color, but white, American Caucasians. The demographics also indicate that women who reflect unconventional perspectives or ideas in their works or lifestyles are less likely to be included in $B C L$, as are female poets.

The titles by the forty-two authors in the sample that appear in $B C L$ are documented in this study. There are a total of 513 titles included in the three editions of $B C L$. Some titles are repeated in several editions. Therefore, 318 unique titles appear in $B C L$ for the sample of authors. Table 3 presents the number of titles listed in each edition of $B C L$ by chronological division.

As the table indicates, there is little difference between the three editions of $B C L$ in the number of titles included in the representation of the Middle Ages and Renaissance and the seventeenth and eighteenth centuries. There is a slight decline in the number of titles included in the representation of the literature of the nineteenth century from $B C L 1$ to $B C L 2$ and an increase in the number of titles included in this representation from $B C L 2$ to $B C L 3$. There is a steady decline in the number of titles included in the representation of the turn-of-thecentury literature from $B C L 1$ to $B C L 2$ to

TABLE 3

NUMBER OF TITLES INCLUDED IN $B C L^{*}$

\begin{tabular}{lcccc}
\hline $\begin{array}{l}\text { Chronological Division } \\
\text { of Titles included in BCL } \\
\text { within Each NALW Division }\end{array}$ & $\begin{array}{c}\text { Total Number of } \\
\text { Titles Included } \\
\text { in BCL within } \\
\text { Each NALW } \\
\text { Division }\end{array}$ & $\begin{array}{c}\text { Number of } \\
\text { Titles Included } \\
\text { in BCL1 (1967) }\end{array}$ & $\begin{array}{c}\text { Number of } \\
\text { Titles Included } \\
\text { in BCL2 (1975) }\end{array}$ & $\begin{array}{c}\text { Number of } \\
\text { Titles Included } \\
\text { in BCL 3 (1988) }\end{array}$ \\
\hline $\begin{array}{l}\text { Middle Ages and the } \\
\text { Renaissance }\end{array}$ & 2 & 1 & 0 & 1 \\
17th and 18th centuries & 5 & 1 & 2 & 2 \\
19th century & 42 & 13 & 11 & 18 \\
Turn-of-the-century & 32 & 15 & 11 & 6 \\
Modernist & 217 & 111 & 54 & 52 \\
Contemporary & 215 & 42 & 58 & 115 \\
Total number of titles & 513 & 183 & 136 & 194 \\
\hline
\end{tabular}

- These are not unique titles. Some of the titles are repeated in several editions of $B C L$. There are a total of 318 unique titles in this sample. 
$B C L 3$. This decline in the number of titles corresponds with the decline in the number of titles represented in the three editions of $B C L$ for this same chronological division, as illustrated in table 3 . The number of titles included in the representation of the modernist period decreases about 48 percent from BCL1 to $B C L 2$ and decreases by two titles from $B C L 2$ to $B C L 3$. The high number of titles included in BCL1 may be attributed to the fact that the authors included in the modernist period had reached their critical acclaim and had published a majority of their works prior to the publication of $B C L 1$. The number of titles included in the representation of the contemporary period increases by just over 36 percent from $B C L 1$ to $B C L 3$ and increases by sixteen titles from $B C L 1$ to $B C L 2$. This may be attributed to the fact that approximately 40 percent of the contemporary authors included in NALW had not published their works until after 1970 . Those who had published prior to the 1967 publication date of $B C L 1$ and the 1975 publication date of $B C L 2$ may not have achieved critical acclaim by BCL1 and $B C L 2$ publication dates.

Eleven authors have the greatest number of titles included in the three editions of $B C L$. Table 4 presents the number of titles by each of these authors included in each edition of $B C L$ by chronological division.

There is a steady decline in the number of titles by Lady Isabella Augusta Gregory, a turn-of-the-century author, included in each edition of $B C L$.

Among the modernist authors, Gertrude Stein, Willa Cather, Elizabeth Bowen, and Edith Sitwell, the number of titles included in $B C L$ progressively decreases in each edition. This again is consistent with the decline in titles represented for the modernist period in each edition of $B C L$ portrayed in table 3. The representation of Virginia Woolf's work in BCL does not follow this trend of decline. This may be attributed to her vast critical acclaim. The large number of titles included in BCL1 for these writers of the modernist period may be attributed to the fact that they had reached their critical acclaim and had published a majority of their works prior to the publication of BCL1.

All of the contemporary authors listed above, except for Mary McCarthy, have more titles included in BCL3 than included in either $B C L 1$ or $B C L 2$. This may be because these authors had not published their works until after 1970 . Those who had published prior to the 1967 publication date of BCL1 and the 1975 publication date of BCL2 may not have achieved critical acclaim prior to the $B C L 1$ and $B C L 2$ publication dates.

For all of the authors listed above, except for Joyce Carol Oates, Margaret Drabble, and Eudora Welty, there is a reduction of titles included in BCL2 in comparison to BCL1. This supports Wadsworth's criticism of the reduction in number of titles for specific authors in $B C L 2$ in comparison to $B C L 1$. $^{47}$ The reduction of titles in BCL2 and BCL3 for Mary McCarthy and in BCL3 for Gertrude Stein and Elizabeth Bowen in comparison to $B C L 1$ may be a result of the inclusion of collected works by these authors.

Willa Cather is represented by twentythree titles in BCL1 and by two titles in $B C L 2$ and three titles in BCL3. A majority of the titles listed in $B C L 1$ are single stories, while BCL2 and BCL3 include a collection of short fiction and a collection of novels and short stories. The inclusion of these collections may also be the reason for omitting the individual titles in BCL2 and $B C L 3$. The decline in the number of titles for the other authors cannot be attributed to the inclusion of collected works. Another possible theory for the reduction of titles by Willa Cather included in BCL2 and BCL 3 is the removal of Willa Cather from the canon. By reducing the number of titles, the contributors of $B C L 2$ and $B C L 3$ may have participated in the removal of Willa Cather from the canon as did her critics in the $1930 \mathrm{~s}$ and $1940 \mathrm{~s}^{48}$

Heinzkill believes that publishers are a factor in the determination of the canon. "Texts are in print because they are canonical, a non-canonical text is not kept in print" and therefore cannot acquire a wide readership or a place in the 
TABLE 4

AUTHORS WITH GREATEST NUMBER OF TITLES INCLUDED IN $B C L$

\begin{tabular}{|c|c|c|c|}
\hline $\begin{array}{l}\text { Authors with Greatest Number } \\
\text { of Titles Included in Each } B C L \\
\text { within NALW Divisions }\end{array}$ & $\begin{array}{l}\text { Number of } \\
\text { Titles Included } \\
\text { in BCL1 (1967) }\end{array}$ & $\begin{array}{l}\text { Number of } \\
\text { Titles Included } \\
\text { in } B C L 2(1975)\end{array}$ & $\begin{array}{l}\text { Number of } \\
\text { Titles Included } \\
\text { in } B C L 3(1988)\end{array}$ \\
\hline
\end{tabular}

\section{Turn-of-the-century}

Lady Isabella Augusta Gregory (1852-1932) ${ }^{1}$

11

9

6

5

Modernist

Gertrude Stein (1874-1946) ${ }^{2}$

Virginia Woolf (1882-1941) ${ }^{3}$

28

Willa Cather (1873-1947)

26

Elizabeth Bowen (1899-1973) ${ }^{5}$

25

Contemporary

Doris Lessing (1919- )

Mary McCarthy (1912- $)^{9}$

8

Eudora Welty (1909- $)^{10}$

1 A 1963 edition of Selected Plays by Lady Gregory is included in all three editions of BCL. Seven Short Plays is included in BCL1 and BCL2. BCL3 includes a 1976 publication of Lady Gregory's autobiography.

${ }^{2} B C L 1$ includes individual titles by Gertrude Stein. BCL2 and BCL3 include Selected Writings of Gertrude Stein and Selected Operas and Plays of Gertrude Stein. BCL3 also includes a selection that is not included in $B C L 1$ or $B C L 2$.

${ }^{3} B C L 3$ includes the addition of four newer publications consisting of Virginia Woolf's letters, diary, and unpublished autobiographical writings, as well as a complete book of shorter fiction.

${ }^{4} B C L 1$ includes individual titles by Willa Cather. BCL2 and BCL3 both include a collection of short fiction, 1892-1912 and a collection of the novels and short stories of Willa Cather.

${ }^{5}$ BCL3 includes a 1981 collection of Elizabeth Bowen's short stories.

${ }^{6}$ BCL1 and BCL2 include Collected Poems of Edith Sitwell's. BCL2 and BCL3 include A Poet's Notebook.

${ }^{7}$ Two of the Joyce Carol Oates titles included in BCL2 are not included in BCL3.

${ }^{8}$ The five titles of Margaret Drabble included in BCL2 are also included in BCL3.

${ }^{9} B C L 2$ and $B C L 3$ include a collection of Mary McCarthy's literary essays.

10 Two of the eight Eudora Welty titles included in BCL1 are not included in BCL2 and BCL3. 
TABLE 5

TYPE OF PUBLISHER IN SAMPLE INCLUDED IN $B C L$

\begin{tabular}{lcc}
\hline Type of Publisher & $\begin{array}{c}\text { \% of Publishers in NAWL } \\
\text { Sample Included in } B C L\end{array}$ & $\begin{array}{c}\text { \% of Titles in NAWL } \\
\text { Sample Included in } B C L\end{array}$ \\
\hline American trade & 50 & 73 \\
University & 18 & 11 \\
British trade & 14 & 7 \\
Small presses & 8 & 6 \\
Unknown & 8 & 2 \\
Academic trade & 1 & 0.3 \\
Australian trade & 1 & 0.3 \\
\hline
\end{tabular}

canon. ${ }^{49}$ Commercially motivated publishers publish those texts that will sell and generate profits, therefore controlling the materials available to consumers. Table 5 presents the type of publisher and percentage of publishers in the sample of fifty authors from $N A L W$ included in $B C L$.

It should be noted that 23 percent of the trade publishers and 47 percent of the university presses listed in $B C L$ for the sample distribute catalogs or lists specifically identifying titles relevant to women's studies or have established series in women's studies. By producing series or catalogs in women's studies, these publishers have identified the importance of and the market for women's studies. ${ }^{50}$ These trade publishers are contributing to and supporting the women's studies field.

Seven percent of the sample titles are published in England by trade publishers. Of the eighty-four publishing companies responsible for the publication of the sample titles included in $B C L$, six of these companies are small presses. Two of these small presses are religious presses; one is a feminist press, one is an African-American press, and one is a college press. In the sample included in $B C L$, one private press is responsible for the publication of seven titles. This press is Hogarth Press, founded by Virginia Woolf and her husband, Leonard Woolf, in the early 1920 s and established in London. ${ }^{51}$ During the years $1922-60$ Hogarth Press published five of Virginia Woolf's titles, one of Edith Sitwell's titles, and one of Gertrude Stein's titles included in $B C L$. These three authors are among those authors of the sample with the greatest number of titles included in $B C L$. The inclusion of the small press, Hogarth Press, may be because of the publicity associated with one of its owners, Virginia Woolf.

This sample of titles and publishers indicates that $B C L$ tends to include trade publishing companies more often than university and small presses. This could be the result of the revenue and time trade publishers expend on advertising in comparison to that of university and small presses. Another possible reason for the large number of trade publishers included in the sample of $B C L$ titles is that library-related journals tend to review titles published by a limited number of large mainstream publishers. ${ }^{52}$

\section{SUMMARY AND \\ RECOMMENDATIONS FOR FUTURE STUDY}

The results of this exploratory study give an indication of the number of women authors included in NALW (an important canon of women's literature) who are also included in the three editions of $B C L$ (an important canon of the academic library field). Since $B C L$ is a recommended core collection for undergraduate libraries and the literature suggests it is used for collection development and selection as well as evaluation and assessment of academic libraries, it is important that future work examine and compare the authors and titles included in this core collection to undergraduate programs.

The women authors' movement between editions of $B C L$ supports Robert 
Alter's contention that authors move from the center of the canon to its margins, reflecting the values of those members of society who are in authority and who exert a symbolic power over the formation of the canon..$^{53}$ It also reflects the evolution and growth of the women's studies field. The fluctuation of the number of titles included in $B C L$ for this sample of authors may also be an indication of the mutability and instability of the entity of the canon. The reduction of titles by Gertrude Stein, Willa Cather, and Edith Sitwell from the first edition of $B C L$ to the third edition suggests a decanonization of these authors.

Although 80 percent of the authors included in NALW are also included in $B C L$, the findings indicate that 55 percent of the women excluded from the library field canon are unconventional members of society rather than the societal norm. $B C L$, an important canon of the academic library field, again supports Alter's idea of the canon as "a reflection in any society of the values" supported or favored by a learned elite. ${ }^{54}$

Sixty-four percent of the publishers included in $B C L$ are trade publishers, indicating that titles published by trade publishers are more likely to be included in $B C L$ than those published by university or small presses. This may be influenced by the publishers' control of the titles published, access to their public, trade publishers relationship with a learned elite, and the marketing strategies employed by trade publishers. This may also determine the titles reviewed in library journals, which tend to be published by a limited number of large mainstream publishers. ${ }^{55}$

This exploratory study supports Alter's perspective, noted above, that the literary canon is a reflection of the values favored by a learned elite. The study also suggests that the learned elite may include the authors, editors, and contributors of core collections or lists, publishing companies, and review sources.

More investigation of the uses of $B C L$ by academic librarians is needed to identify the extent of its utility. This study also indicates a need for further studies documenting women authors, AfricanAmerican authors, and Native-American authors in BCL. A comparison of the number of women and minority authors included in each edition of BCL would also assist in documenting changes in the canon. An examination of the publishers of the titles included in the three editions of $B C L$ by these women and minority authors would also be a great contribution to the library, women's studies, and literature fields.

It would be interesting to sample the number of male authors and their titles included in the literature section of each of the editions of $B C L$ and to compare this sample to the number of female authors and their titles included in this section in each of the editions of BCL. Publishers of the titles of both samples could also be analyzed. Further study of the use of review materials in the selection process as well as the publishers of the titles included in these review sources is needed in the library field.

An investigation and analysis of the demographic profiles of the contributors to each edition of $B C L$ would be advantageous in examining the core collection. This information would be useful in identifying those responsible for establishing the canon of the library field and in examining and comparing the trends and characteristics of the authors and titles included in each edition of $B C L$.

The NALW is an accepted canon in the field of women's studies, but is it an accepted canon in the field of literature? By using the 148 authors included in NALW as the sample, the inclusion of these authors in other literary anthologies attempts to answer this question. A comparison of the number of male and female authors included in other literary anthologies would also assist in documenting the inclusion of women in the canon. This comparison could also include minority authors in order to document their inclusion in the literary canon.

This exploratory study has identified some of the characteristics of $B C L$ in relation to literature by women. It is only 
a beginning or starting point. Additional questions pertaining to the women's studies and library fields have been identified by this investigation and need to be addressed. The women's studies field is relatively young in comparison to other fields and is continually evolving and growing. Future study and research is needed to reflect and document this evolution and growth.

\section{REFERENCES}

1. Melvin J. Voight and Joseph H. Treyz, "Preface," Books for College Libraries (Chicago: ALA, 1967), v.

2. Ibid.

3. Association of College and Research Libraries, "Introduction," Books for College Libraries: A Core Collection of 40,000 Titles, 2d ed. (Chicago: ALA, 1975), vii.

4. Ibid.

5. Virginia Clark, "Introduction," Books for College Libraries: A Core Collection of 50,000 Titles, 3d ed. (Chicago: ALA, 1988), vii.

6. Lee Ash, "Review of Books for College Libraries," Library Journal 92 (Oct. 1, 1967): 3390; and Robert W. Wadsworth, "Review of Books for College Libraries," California Librarian 28 (Oct. 1967): 245-47.

7. R. E. Moore, "The Checklist Selection Syndrome: Review of Books for College Libraries: A Core Collection of 40,000 Titles," PNLA Quarterly 40 (Spring 1976): 22; and Lee Ash, "Review of Books for College Libraries: A Core Collection of 40,000 Titles," Library Journal 101 (Mar. 1, 1976): 672-73.

8. John M. Budd, "The Utility of a Recommended Core List: An Examination of Books for College Libraries," 3d ed., Journal of Academic Librarianship 17 (July 1991): 140-44.

9. Ash, "Review ....: A Core Collection"; and Moore, "The Checklist."

10. Clark, "Introduction," ix.

11. Ibid.

12. Thomas Gaughan, "Review of Books for College Libraries: A Core Collection of 40,000 Titles," RQ 16 (Fall 1976): 77-79; and Moore, "The Checklist."

13. Gaughan, "Review.".

14. Robert W. Wadsworth, "Review of Books for College Libraries: A Core Collection of 40,000 Titles," College \& Research Libraries 37 (Jan. 1976): 71.

15. "Reference and Subscription Books Reviews: Review of Books for College Libraries: A Core Collection of 40,000 Titles," Booklist 72 (May 1, 1976): 1284-86; Michael Kreyche, "BCL3 and NOTIS: An Automated Collection Analysis Project," Library Acquisitions: Practice \& Theory 13 (1989): 323-28; Barbara MacAdam, "Review of Books for College Libraries: A Core Collection of 50,000 Titles," Library Journal 114 (Feb. 15, 1989): 181; and James Rettig, "Review of Books for College Libraries: A Core Collection of 50,000 Titles," Wilson Library Bulletin 63 (Jan. 1989): 120.

16. Stanley Shabowich, An Approach to Assessment of Quality of a University Library Collection (Hammond, Ind.: Purdue Univ., 1977).

17. Budd, "The Utility"; and Richard Heinzkill, "The Literary Canon and Collection Building," Collection Management 13 (1990): 51-64.

18. Joan Ariel, ed. Building Women's Studies Collections: A Resource Guide (Middletown, Conn.: CHOICE, 1987).

19. Susan E. Searing, An Introduction to Library Research in Women's Studies (Boulder, Colo.: Westview, 1985).

20. Helen B. Josephine and Deborah K. Blouin, "New Reference Sources on Women: An Analysis and Proposal," The Reference Librarian 15 (Fall 1986): 109-22; Mark Emery, "Considerations regarding Women's Studies Collection Development in Academic Libraries," Collection Management 10 (1988): 85-94; and Catherine Stimpson, "Access or Impasse?: Meeting the Research Needs of Women's Studies," (paper presented at ALA Annual Conference, Womens' Studies Section, June 24, 1990, Chicago).

21. Stimpson, "Access or Impasse?"

22. Searing, An Introduction; and Stimpson, "Access or Impasse?" 
23. Catherine R. Loeb, Susan E. Searing, and Esther F. Stineman, Women's Studies: A Recommended Core Bibliography, 1980-1985 (Englewood, Colo.: Libraries Unlimited, 1987).

24. Jane Tompkins, Sensational Designs: The Cultural Work of American Fiction 1790-1860 (New York: Oxford Univ. Pr., 1985); Susan H. Aiken, "Women and the Question of Canonicity," College English 48 (Mar. 1986): 288-301; Cathy N. Davidson, Revolution and the Word: The Rise of the Novel in America (New York: Oxford Univ. Pr., 1986); Nancy K. Miller, "Parable and Politics: Feminist Criticism in 1986," Paragraph: The Journal of the Modern Critical Theory Group 8 (Oct. 1986): 40-54; Susan S. Heinzelman, "Hard Cases, Easy Cases and Weird Cases: Canon Formation in Law and Literature," Mosaic: A Journal for Interdisciplinary Study of Literature 21 (Spring 1988): 59-72; Robert Alter, The Pleasures of Reading: In an Ideological Age (New York: Simon \& Schuster, 1989); Sharon O’Brien, “Becoming Noncanonical: The Case against Willa Cather," in Reading in America, ed. Cathy N. Davidson (Baltimore: Johns Hopkins Univ. Pr., 1989); and Jane Tompkins, "Literary Canon," in International Encyclopedia of Communications, ed. Erik Barnouw and others (New York: Oxford Univ. Pr., 1989).

25. O’Brien, "Becoming Noncanonical," 243.

26. Ibid., 248.

27. Alter, The Pleasures of Reading, 25.

28. Tompkins, Sensational Designs; and Sandra M. Gilbert and Susan Gubar, The Norton Anthology of Literature by Women: The Tradition in English (New York: Norton, 1985).

29. Laura Shapiro, "'A' Is for Austen, 'B' Is for Bronte ....," Newsweek, July 15, 1985, 64B-64F.

30. Sally Mitchell, "Review of The Norton Anthology of Literature by Women, by Sandra M. Gilbert and Susan Gubar," Library Journal 111 (Apr. 15, 1986): 34.

31. Booklist 81 (Apr. 15, 1985): 1152.

32. Gilbert and Gubar, The Norton Anthology, xxvii.

33. Gail Godwin, "Review of The Norton Anthology by Women, by Sandra M. Gilbert and Susan Gubar," New York Times Book Review, Apr. 28, 1985, 13; Phyllis Rose, "Review of The Norton Anthology of Literature by Women, by Sandra M. Gilbert and Susan Gubar," Atlantic, Aug. 1985, 88; and Denis Donoghue, "Review of The Norton Anthology of Literature by Women, by Sandra M. Gilbert and Susan Gubar," New Republic, July 15, 1986, 30.

34. Lee Edwards, "Review of The Norton Anthology of Literature by Women, by Sandra M. Gilbert and Susan Gubar," The Women's Review of Books (June 1986), 17; and Heinzelman, "Hard Cases, Easy Cases and Weird Cases," 1988.

35. Gilbert and Gubar, The Norton Anthology, xxviii-xxxi.

36. Shari Benstock, "Women's Literary History: To be Continued," Tulsa Studies in Women's Literature 5 (Fall 1986): 175.

37. Rita D. Jacobs, "Review of The Norton Anthology of Literature by Women, by Sandra M. Gilbert and Susan Gubar," World Literature Today 60 (Spring 1986): 314-15; and Shapiro, "'A' Is for Austen."

38. Sally Mitchell, "Review of The Norton Anthology of Literature by Women, by Sandra M. Gilbert and Susan Gubar," Library Journal 110 (Apr. 15, 1985): 74; and Mitchell, "Review," 34.

39. Josephine and Blouin, "New Reference Sources."

40. These categorizations are based on substantiated evidence and not conjecture.

41. Gilbert and Gubar, The Norton Anthology, 1206.

42. Ibid., 2247.

43. Elaine Kim, "Workshop conducted at the University of Wisconsin-Madison," Spring 1990.

44. Gilbert and Gubar, The Norton Anthology, 1206.

45. Ibid., 72.

46. Ibid., 1404 .

47. Wadsworth, "Review."

48. O'Brien, "Becoming Noncanonical.".

49. Heinzkill, "The Literary Canon," 55.

50. Ariel, Building Women's Studies.

51. Gilbert and Gubar, The Norton Anthology.

52. Judith Serebnick, "An Analysis of Publishers of Books Reviewed in Key Library Journals," Library and Information Science Research 6 (July/Sept. 1984): 289-303. 
53. Alter, The Pleasures of Reading.

54. Ibid., 25-26.

55. Serebnick, "An Analysis of Publishers of Books."

\section{APPENDIX A}

\section{Literature of the Middle Ages and the Renaissance}

Julian of Norwich (1342-?)

Mary Sidney Herbert, Countess of Pembroke (1561-1621)

\section{Literature of the Seventeenth and Eighteenth Centuries}

Margaret Cavendish, Duchess of Newcastle (1623-74)

Mary Rowlandson (c.1636-c.1678)
Anne Killigrew (1660-85)

Lady Mary Wortley Montagu (1689-1762)

Phillis Wheatley (c.1753-84)

\section{Literature of the Nineteenth Century}

Dorothy Wordsworth (1771-1855)

Mary Shelley (1797-1851)

Margaret Fuller (1810-50)

Elizabeth Cady Stanton (1815-1902)
Linda Brent (1818-98)

Elizabeth Drew Stoddard (1823-1901)

Emily Dickinson (1830-86)

Louisa May Alcott (1832-88)

\section{Turn-of-the-Century Literature}

Sarah Orne Jewett (1849-1909)

Lady Augusta Gregory (1852-1932)
Mary Elizabeth Coleridge (1861-1907)

Charlotte Mew (1870-1928)

\section{Modernist Literature}

Willa Cather (1873-1947)

Gertrude Stein (1874-1946)

Virginia Woolf (1882-1941)

Anna Wickham (1884-1947)

Anzia Yezierska (c.1885-1970)

Stevie Smith (1902-71)

Lillian Hellman (1907-84)

Eudora Welty (1909-)

Mary McCarthy (1912-)

Tillie Olsen (1913-)

Judith Wright (1915-)

Gwendolyn Brooks (1917-)

Doris Lessing (1919-)

Grace Paley (1922-)

Flannery O'Connor (1925-64)

Margaret Laurence (1926-)
Edith Sitwell (1887-1964)

Mourning Dove (Hum-Ishu-Ma) (1888-1936)

Djuna Barnes (1892-1982)

Jean Rhys (1894-1979)

Elizabeth Bowen (1899-1973)

\section{Contemporary Literature}

Ursula K. Le Guin (1929-)

Toni Morrison (1931-)

Edna O'Brien (1932-)

Kamala Das (1934-)

Marge Piercy (1936-)

Joyce Carol Oates (1938-)

Margaret Drabble (1939-)

Maxine Hong Kingston (1940-)

Louise Gluck (1943-)

Leslie Marmon Silko (1948-) 